\title{
Microbial hydrolytic enzyme activities in deep-sea sediments
}

\author{
A. Boetius* \\ Institut für Hydrobiologie und Fischereiwissenschaft, Abteilung Biologische Ozeano- \\ graphie; Zeiseweg 9, 22765 Hamburg, Germany
}

\begin{abstract}
The potential hydrolysis rates of five different hydrolytic enzymes were determined in deep-sea sediments from the northeast Atlantic (BIOTRANS area) in March 1992. Fluorogenic substrates were used to assay extracellular $\alpha$ - and $\beta$-glucosidase, chitobiase, lipase and aminopeptidase. The potential activity of most of the enzymes investigated decreased to a minimum within the upper two centimetre range, whereas aminopeptidase was high over the upper five centimetre range. Exceptions were found when macrofaunal burrows occurred in the cores, always increasing the activities of some hydrolases, and therefore indicating the impact of bioturbation on degradation rates. The most striking feature of the investigated enzyme spectrum was the 50-2000 times higher specific activity of the aminopeptidase, compared with the other hydrolases. The activity of hydrolytic enzymes most likely reflects the availability of their respective substrates and is not a function of bacterial biomass.
\end{abstract}

\section{INTRODUCTION}

Sedimentation of organic material from the euphotic zone is the main energy input into the abyssal benthic food-web (Rowe et al., 1991; Pfannkuche, 1992; Deming \& Yager, 1992). The energetic value and composition of particulate organic matter are altered during the latter's transport through the water column, due to biological and chemical processes (Alldredge \& Silver, 1988). The utilization of the organic input into the abyss by benthic organisms depends on the age and the composition of the detritus (Lochte, 1992). The main contribution to degradation of organic material in deep-sea sediments comes from micro-organisms, which represent up to $90 \%$ of the benthic biomass (Tietjen, 1992). Bacteria are known for their ability to digest various organic compounds with specific extracellular hydrolases (Chrost, 1991). Only monomers and small oligomers can be incorporated by bacterial cells and enter physiological pathways. Therefore, extracellular enzymatic hydrolysis is the key process in the degradation of organic material (Billen, 1982; Meyer-Reil, 1991). Since the production of most of the extracellular hydrolases is substrate-inducible (Priest, 1984), the potential hydrolytic activity of specific enzymes may reflect the availability of their respective organic substrates.

Different fluorogenic substrates were used to investigate a spectrum of hydrolases in deep-sea sediments. Since fluorometric measurements are sensitive enough to allow

\footnotetext{
- Present address: Alfred-Wegener-Institut für Polar- und Meeresforschung, Columbus-Straße, D-27515 Bremerhaven
} 
short incubation times of the samples, "snapshots" of the potential enzyme activities within the sediments could be obtained. Hydrolytic enzymes are named after the substrates they respectively cleave (IUB Enzyme Nomenclature, 1973). Some enzymes may have a broader specificity, enabling them to hydrolyse other substrates with a lower activity.

\section{METHODS}

The BIOTRANS area is situated in the northeast Atlantic at $47^{\circ} \mathrm{N}$ and $19^{\circ} \mathrm{W}$ at $4500 \mathrm{~m}$ depth (Pfannkuche et al., 1990). The investigations were carried out on sediment samples recovered with a multiple corer (Barnett et al., 1984) during the "Meteor" cruise 21/1 in March/April 1992.

Methylumbelliferyl (MUF) and methylcoumarinylamid (MCA) derivatives were used to measure the potential enzymatic activity of different hydrolases: MUF- $\alpha$ - and MUF- $\beta$ glucoside for the respective glucosidases, MUF-N-acetylglucosamine for chitobiase, MUF-stearate for lipase and L-leucine-MCA for aminopeptidase. The enzymes liberate the fluorochrome from the nonfluorescent substrate in a 1:1 ratio.

The method used is based on previous work of Hoppe (1983) and Meyer-Reil (1986). Three to five sediment cores from one multiple corer were sliced directly after sampling in one-centimetre thick layers, and slices from the same sediment depth were mixed to avoid small-scale variations. From the mixtures, sediment slurries were prepared with sterile filtered deep-sea water in a $1: 1$ dilution.

Samples from each slurry were amended with concentrations of substrate at saturation level which had been tested in advance. The samples were incubated at in-situ temperature $\left(2^{\circ} \mathrm{C}\right)$ with different MUF/MCA substrates. At five time-intervals during four hours of incubation, subsamples were removed and diluted $1: 2$ with sterile filtered deepsea water. After the addition of $0.25 \mathrm{ml}$ of borate buffer $(\mathrm{pH} \mathrm{10)}$, the subsamples were centrifuged (10 $\mathrm{min}, 4000 \mathrm{U} / \mathrm{min})$. The fluorescence was immediately measured at $365 \mathrm{~nm}$ excitation and $455 \mathrm{~nm}$ emission. The fluorescence units were calibrated by measuring known concentrations of methylumbelliferone. The enzyme activity is expressed as velocity of hydrolysis $\left(\mathrm{nmol} \mathrm{m} \mathrm{l}^{-1}\right.$ sediment $\mathrm{h}^{-1}$ ). Data from 6 different multiple corer samples taken over a time-interval of eleven days (March 25th to April 4th, 1992) are presented as mean values of potential enzyme activities in the BIOTRANS area.

Samples with significant deviations from the usual distribution of enzyme activities due to the occurrence of biogenic structures in the cores were excluded and are separately shown.

\section{RESULTS}

Activities of specific hydrolases and their profiles with sediment depth

$$
\alpha \text {-Glucosidase and } \beta \text {-Glucosidase }
$$

These enzymes hydrolyse two groups of saccharides: $\alpha$-glucosidic bonds occur in storage compounds of plants and animals like starch and glycogen which are easily degradable; $\beta$-glucosidic bonds make up structural compounds like cellulose, as in plantwall material, and mucopolysaccharides, as in invertebrate slimes. Not many organisms beside bacteria can digest $\beta$-glucosidic substrates. 
The potential activity of $\alpha$-glucosidase was very low and did not change much with sediment depth (Fig. 1). The activity of $\beta$-glucosidase was ten times higher, sharply decreasing after a maximum at the sediment surface (Fig. 2).

\section{Chitobiase}

Chitin is an abundant structural polysaccharide. Crustacean shells, as well as their fecal membranes, consist of chitin. Chitobiase hydrolyses the bonds between the $\mathrm{N}$ acetyl-glucosamine monomers; it also cleaves the muramin disaccharides in bacterial cell walls. The potential activity of chitobiase was five times higher than $\beta$-glucosidase; their profiles were alike in the exponential decrease with sediment depth (Fig. 3).

\section{Lipase}

The substrate used (MUF-Stearate) is the monoacylester of a long-chain fatty acid, as in waxes, the typical storage lipids of animals.

The enzymatic activity of lipase was about as high as $\beta$-glucosidase at the sediment surface, rapidly decreasing to detection limit below $2 \mathrm{~cm}$ sediment depth (Fig. 4).

\section{Aminopeptidase}

This enzyme has a broad specificity and cleaves nearly all L-peptides. Peptide bonds occur in a multitude of compounds, in the easily degradable proteins as well as in very refractory aromatic substances like humic complexes.

A comparison of the investigated hydrolases revealed that aminopeptidase had a 50-2000 times higher potential than the other enzymes. Furthermore, its profile was

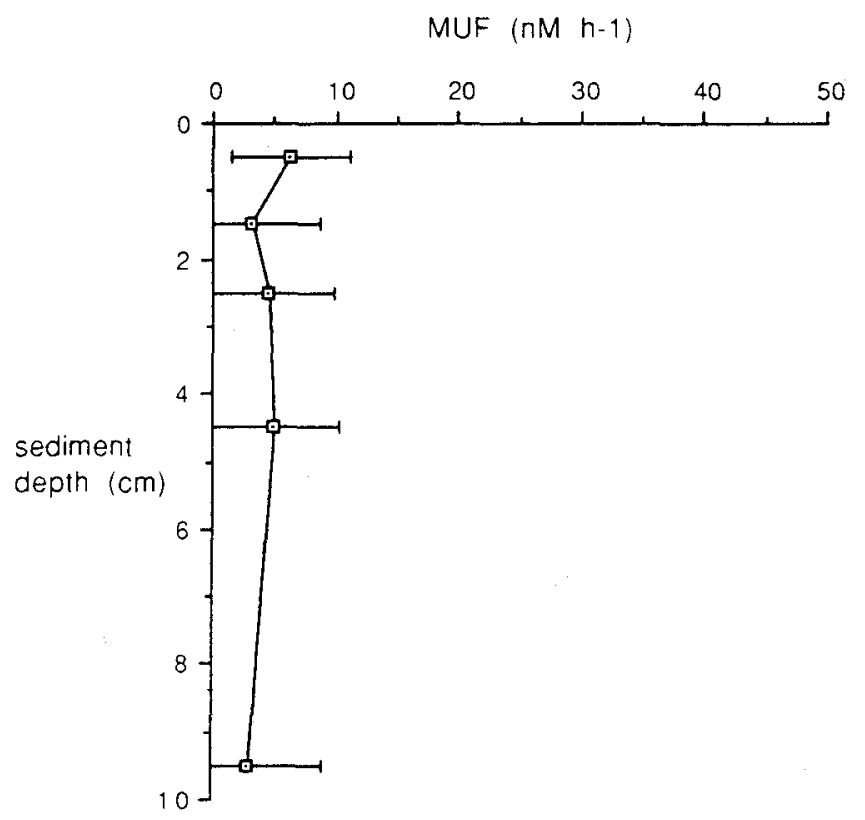

Fig. 1. Hydrolysis of MUF- $\alpha$-glucoside. Sediment profile from BIOTRANS area $(\mathrm{n}=6)$ 


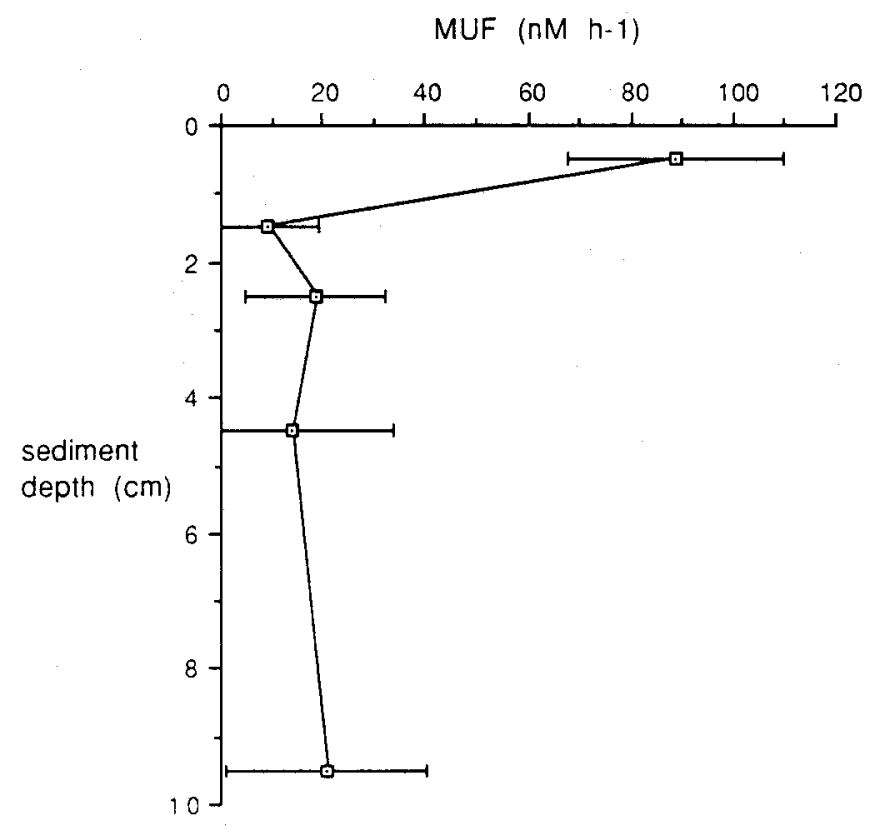

Fig. 2. Hydrolysis of MUF- $\beta$-glucoside. Sediment profile from BIOTRANS area $(n=6)$

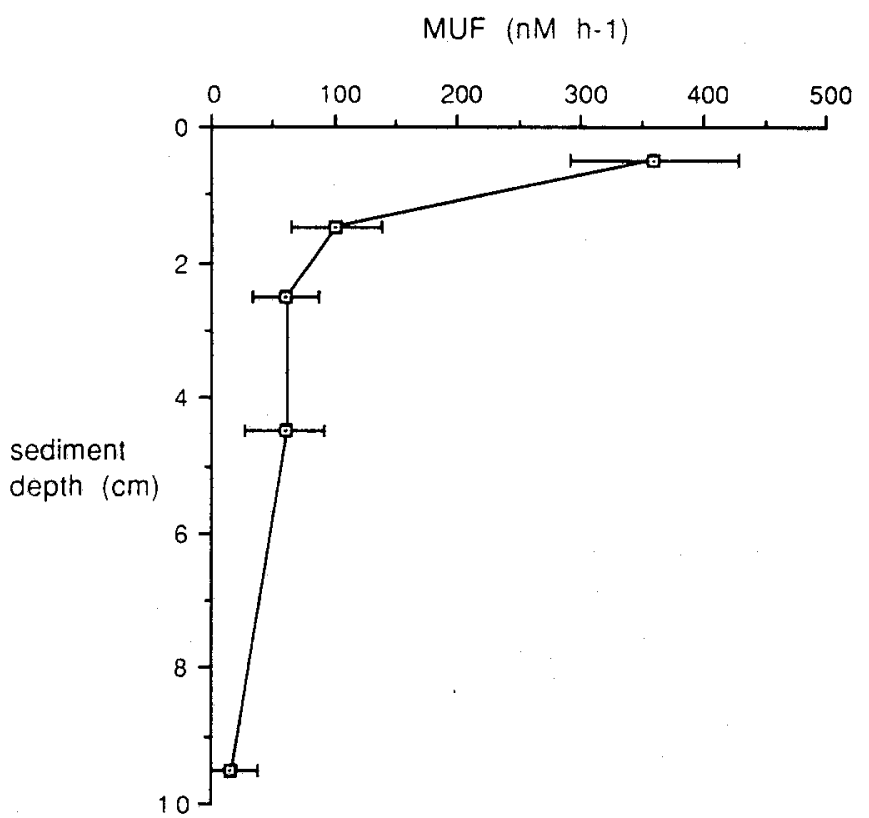

Fig. 3. Hydrolysis of MUF-N-acetyl-glucosamine. Sediment profile from BIOTRANS area $(n=6)$ 


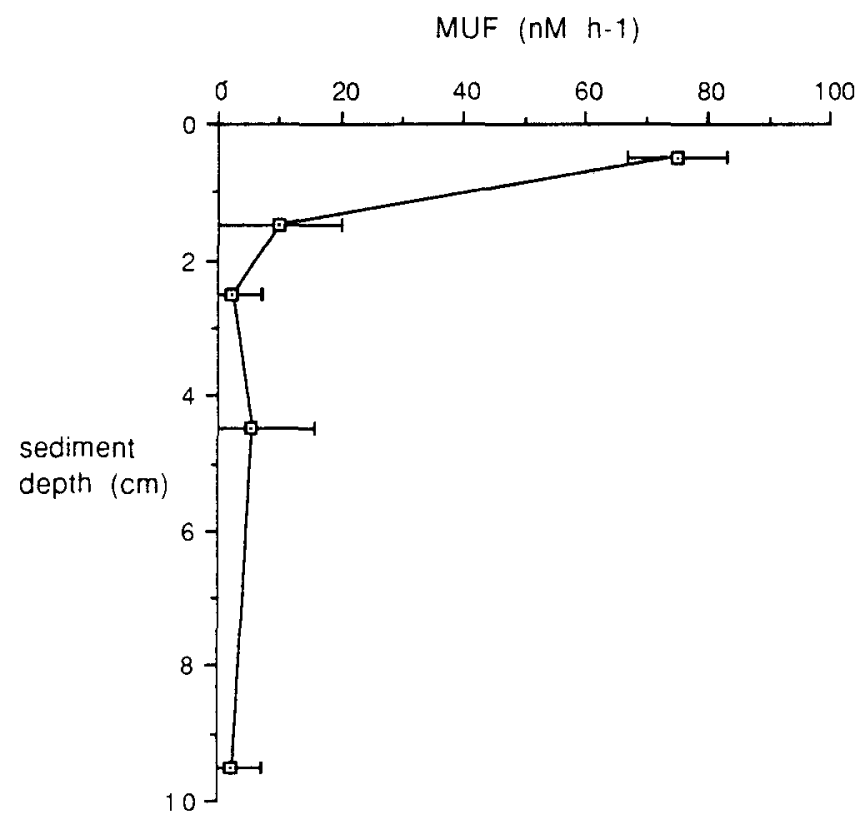

Fig. 4. Hydrolysis of MUF-stearate. Sediment profile from BIOTRANS area $(n=6)$

completely different, showing a subsurface maximum in $2 \mathrm{~cm}$ or $3 \mathrm{~cm}$ sediment depth (Fig. 5). The decrease with sediment depth was slower than that found for the other hydrolases.

\section{Influence of macrofaunal structures}

Groups of vertical macroscopic burrows, stretching from $1 \mathrm{~cm}$ to $10 \mathrm{~cm}$ sediment depth, were found in the sediments of several multiple corer samples from the BIOTRANS area. Even after mixing the sediment layers of 3-5 different cores, a clear difference from the usual type of profiles could be found in the distribution of enzymatic activity. A significant increase in activity was measured, especially at the bottom of burrows, leading to "reversed" profiles (Figs 5, 6, 7). No impact on the activity of aminopeptidase was found.

\section{DISCUSSION}

\section{Activities of specific hydrolases}

The potential activities of specific hydrolases indicate the microbial reaction to the pool of organic matter (Hoppe, 1983), which consists of a variety of compounds.

In deep-sea sediments from the BIOTRANS area, aminopeptidase had the highest activity of all investigated enzymes. The ranking of the activity of the investigated 


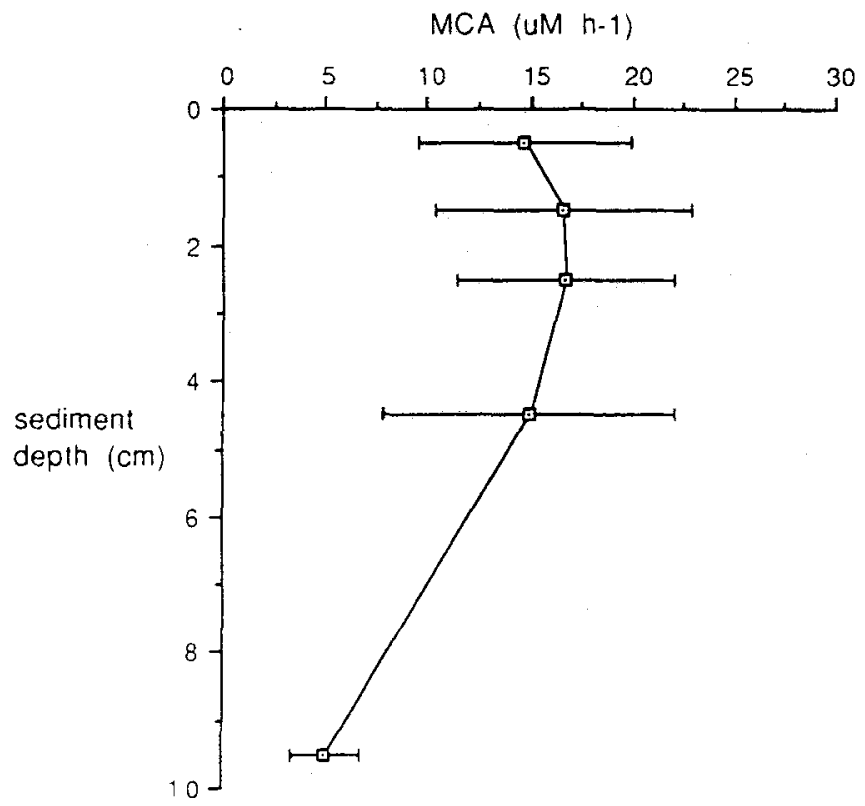

Fig. 5. Hydrolysis of L-leucine-MCA. Sediment profile from BIOTRANS area $(n=6)$

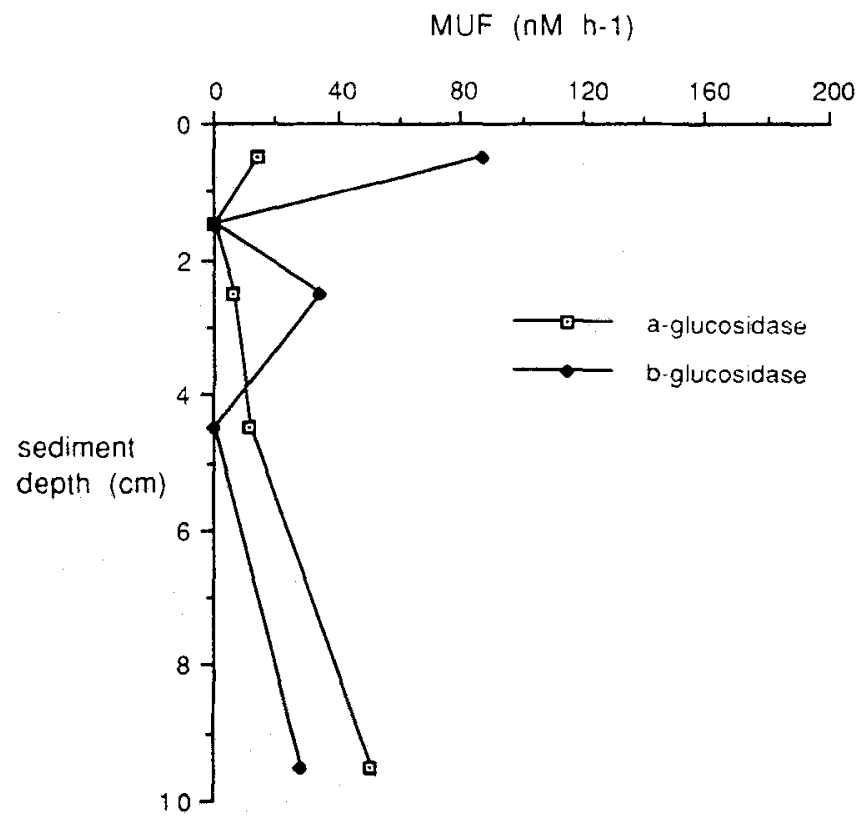

Fig. 6. Hydrolysis of MUF- $\alpha$ - and MUF- $\beta$-glucoside. Sediment profile from BIOTRANS area, 1.4. 1992. In three of the four mixed cores several macrofaunal burrows were observed 


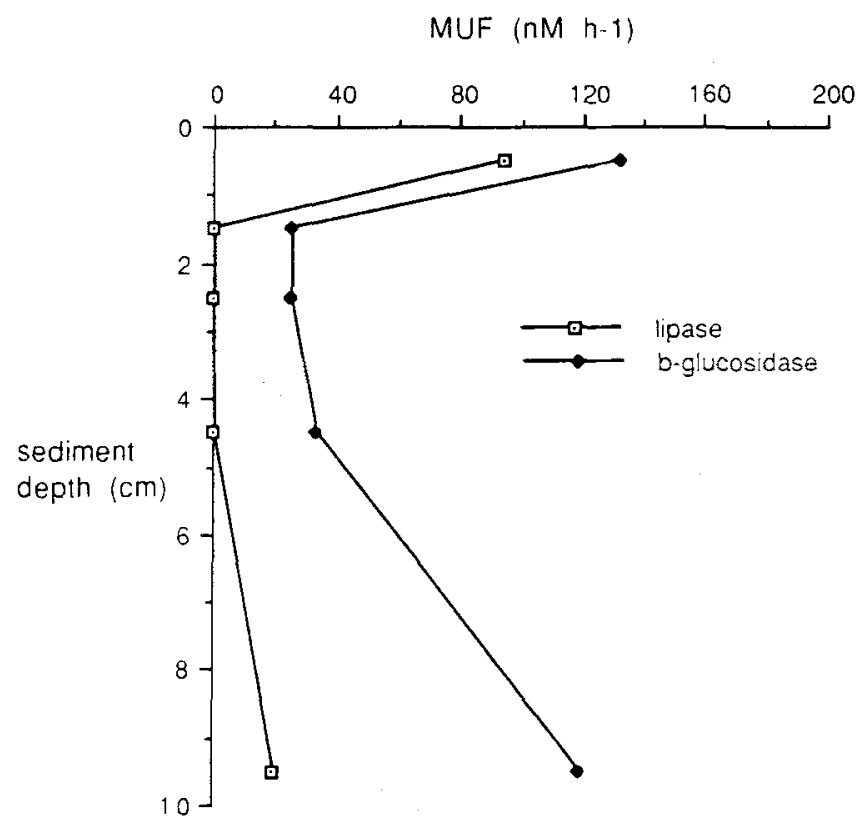

Fig. 7. Hydrolysis of MUF- $\beta-$ glucoside and MUF-stearate. Sediment profile from BIOTRANS area, 27. 3. 1992. In the three mixed cores several macrofaunal burrows were observed. A polychaete was recovered from one of the burrows

saccharidases (chitobiase $>\beta$-glucosidase $>>\alpha$-glucosidase) matches the availability of their respective substrates in deep-sea sediments. Chitin is the most abundant polysaccharide in marine environments with little resources of fresh plant detritus (Smucker \& Kim, 1991). Food deposits in the deep-sea are limited and low in energetic quality. Easily digestable organic materials like $\alpha$-glucosidic compounds and fresh proteins are rare, since they are already degraded during transportation through the water column (Karl et al., 1988).

\section{Distribution of hydrolytic activities with sediment depth}

Chitobiase, $\beta$-glucosidase and lipase activities were found to decrease exponentially with sediment depth. These profiles resemble gradients of the distribution of easily degradable substances (Westrich \& Berner, 1984). Aminopeptidase activity decreased slowly with sediment depth, after showing a subsurface maximum in $\mathrm{cm} 2$ or 3 which, according to our observations, seems typical for this enzyme. This fits with the distribution of proteinaceous materials in the BIOTRANS area (Pfannkuche, unpubl. data), which also decrease slowly with sediment depth, having their maxima between $\mathrm{cm} 2$ and 4 . A significant part of these proteinaceous compounds can be refractory material (Rice, 1982).

Profiles of bacterial numbers (Lochte \& Rheinheimer, 1990) and phospholipids (Boetius, 1992) from the BIOTRANS are show a distribution typical for sediments: the highest values were found at the sediment surface, decreasing slowly with sediment 
depth. Compared with profiles of enzyme activities, it can be concluded that hydrolytic enzyme activities are rather related to their respective organic substrates, than to microbial biomass.

An impact of biogenic structures on the distribution of hydrolytic activity was observed in the sediments from the BIOTRANS area. When macrofaunal tubes were present, higher hydrolytic activities were measured in deeper sediment layers. On top of some cores, detritus particles were found, consisting of aggregated diatoms and coccolithophores. The same material was recovered from the gut of a polychaete (Hemleben, pers. comm.). It is known that microbial activity is enhanced at macrofaunal burrows, because of local accumulation of organic material (Aller \& Yingst, 1978; Aller \& Aller, 1986; Köster \& Meyer-Reil, 1991).

Due to bioturbation and feeding habits of the infauna, organic particles are mixed into the sediment column. This may explain the increase in enzyme activity in deeper sediment layers where burrows occurred. Phospholipid measurements from the same mixtures of sediment layers did not show an impact of the biogenic structures on microbial biomass (Boetius, unpubl. data).

Investigations of enzyme production of different bacteria strains (Priest, 1984) or mixed populations (Chrost, 1991) show that the production of specific hydrolytic enzymes is inducible by their substrates and repressable by their end-products. The changes in the hydrolytic activity per cell were determined by the availability of organic substrates.

Up to now, data on the distribution of different organic compounds within deep-sea sediments are rare. Sedimented particulate organic material first accumulates at the sediment surface, where it is used as food by benthic organisms. By bioturbation it is mixed into deeper sediment layers. Depending on the velocity of this process, as well as on the degradation rate, each organic compound has its typical concentration profile (Berner, 1980; Emerson et al., 1985). Concentrations of labile compounds decrease quickly with sediment depth after their maxima at the sediment surface. Profiles of refractory material are mainly determined by bioturbation rates, which also decrease with sediment depth.

If the production of hydrolytic enzymes is induced by their respective organic substrates, the potential enzyme activities are related to the substrate concentration. Therefore, activity profiles should mirror the distribution of their substrates with sediment depth.

From the results of this investigation, the idea of a close correlation between potential enzyme activities and the availability of organic substances in deep-sea sediments can be supported.

Comparison of hydrolytic activities of deep-sea sediments with those of sediments from other marine environments

The degradation of organic material by production of hydrolytic enzymes is a common feature of heterotrophic bacteria. Therefore, data from different environments can be compared when enzyme activity is normalized with microbial biomass.

Potential activities of specific hydrolases in shallow-water environments show differences from those of deep-sea environments, presumably reflecting the availability of their respective substrates (Table 1). This can be seen in the amount of specific activity as well as in the ranking of different hydrolases. 
The specific hydrolytic activities within all three environments differ by a factor of 1000. In deep-sea sediments from the BIOTRANS area, $\alpha$-glucosidase was only $0.1 \%$ of the specific activity as measured in Kiel fjord surface waters (Hoppe, 1983). The values for $\beta$-glucosidase and chitobiase specific activities in the two environments are comparable. In shallow-water sediments the specific activities of $\beta$-glucosidase, and particularly chitobiase, were substantially higher than in deep-sea sediments (King, 1986). For aminopeptidase a higher specific activity was found in deep sea sediments from the BIOTRANS area than in the Kiel fjord. Aminopeptidase activity in sediments from the BIOTRANS area was also higher than in sediments of Kiel bight, investigated by MeyerReil (1987). Since a different incubation technique (injection of substrate into undisturbed cores) was used, this result can be a methodological effect.

Again, the special role of aminopeptidase in deep-sea sediments is indicated, since it was the only enzyme that had a higher specific activity than in the shallow water environments. The other investigated enzymes in deep-sea sediments from BIOTRANS area showed lower activities; this was expected from the limited food resources in the abyss.

Presumably, the differences in hydrolytic activities per microbial biomass between different environments are related to the availability of organic substrates.

Table 1. Comparison of specific enzyme activities in different marine environments. Specific activities were calculated with typical numbers for the respective environment: deep-sea sediments ca $10^{9}$ cells $\mathrm{ml}^{-1}$, intertidal sediments ca $10^{10}$ cells $\mathrm{ml}^{-1}$, fjord water ca $10^{6}$ cells $\mathrm{ml}^{-1}$. All cited investigations were carried out with MUF substrates at saturation level under in-situ temperature and $\mathrm{pH}$

\begin{tabular}{|c|c|c|c|c|c|c|}
\hline & & $\begin{array}{l}\alpha \text {-Gluco- } \\
\text { sidase }\end{array}$ & $\begin{array}{l}\beta \text {-Gluco- } \\
\text { sidase }\end{array}$ & $\begin{array}{l}\text { Chito- } \\
\text { biase }\end{array}$ & Lipase & $\begin{array}{l}\text { Amino- } \\
\text { peptidase }\end{array}$ \\
\hline \multirow{2}{*}{$\begin{array}{l}\text { Deep-sea sediments } \\
\text { (this investigation) } \\
(0-1 \mathrm{~cm})\end{array}$} & $\begin{array}{l}\text { Hydrolytic activity } \\
\left(\mu M M U F h^{-1}\right)\end{array}$ & 0.006 & 0.089 & 0.36 & 0.075 & 14.7 \\
\hline & $\begin{array}{l}\text { Estimated specific } \\
\text { activity } \\
\left(10^{-20} \mathrm{~mol} \mathrm{~h}^{-1} \mathrm{cell}^{-1}\right)\end{array}$ & 1.2 & 17.8 & 72.0 & 15.0 & 2940.0 \\
\hline \multirow{2}{*}{$\begin{array}{l}\text { Intertidal sediments } \\
(\text { King, 1986) } \\
(0-2 \mathrm{~cm})\end{array}$} & $\begin{array}{l}\text { Hydrolytic activity } \\
\left(\mu \mathrm{M} M \mathrm{MUF}^{-1}\right)\end{array}$ & & 23.2 & 354.0 & 0.0 & \\
\hline & $\begin{array}{l}\text { Estimated specific } \\
\text { activity } \\
\left(10^{-20} \mathrm{~mol} \mathrm{~h}^{-1} \mathrm{cell}^{-1}\right)\end{array}$ & & 232.0 & 3540.0 & 0.0 & \\
\hline \multirow{2}{*}{$\begin{array}{l}\text { Kiel Fjord surface } \\
\text { water } \\
\text { (Hoppe, 1983) }\end{array}$} & $\begin{array}{l}\text { Hydrolytic activity } \\
\left(\mu \mathrm{M} M \mathrm{MUF}^{-1}\right)\end{array}$ & 0.01 & 0.005 & 0.005 & & 0.05 \\
\hline & $\begin{array}{l}\text { Estimated specific } \\
\text { activity } \\
\left(10^{-20} \mathrm{~mol} \mathrm{~h}^{-1} \mathrm{cell}^{-1}\right)\end{array}$ & 100.0 & 50.0 & 50.0 & & 500.0 \\
\hline
\end{tabular}




\section{CONCLUSIONS}

A typical range of potential hydrolytic activity was found for each enzyme. Aminopeptidase had the highest activity, exceeding that of the other investigated enzymes by a factor of 1000 . Chitobiase was the most active saccharidase in deep-sea sediments from the BIOTRANS area. Compared to $\beta$-glucosidase and $\alpha$-glucosidase, the relative activities had a ratio of 5.1:0.1. Lipase activity was as high as that of $\beta$ glucosidase. The enzymatic potential of the investigated hydrolases can be related to the availability of their respective organic substrates.

Each enzyme had its characteristic profile of distribution with sediment depth: the saccharidase and lipase activities decreased exponentially, whereas aminopeptidase showed a subsurface maximum followed by a more linear decrease of activity. These profiles can be related to the distribution of either labile or more refractory organic compounds, respectively, resembling their geochemical gradients as proposed by Gaillard \& Rabouille (1992).

Exceptions to these typical gradients were found when macrofaunal burrows occurred in the samples, raising enzymatic activities in deeper sediment layers. This could be explained by local accumulation of organic material in association with the biogenic structures, indicating their impact on microbial activity in sediments.

A comparison of hydrolytic activities per bacterial cell in marine shallow-water environments shows differences in the relative abundances of hydrolases corresponding to the available organic pool. All enzymes except the peptidase had lower specific activities in the deep-sea sediments.

The results of this investigation suggest a close correlation between availability of organic substrates and microbial hydrolytic enzyme activity in deep-sea sediments.

Acknowledgements. I would like to thank the BIO-C-FLUX group and the crew of R. V. "Meteor" for their help with work at sea, also Dr. Karin Lochte for her helpful comments on the first draft of this manuscript. This investigation was supported by the Bundesministerium für Forschung und Technologie. This is BIOTRANS publication No. 27.

\section{LITERATURE CITED}

Alldredge, A. L. \& Silver, M. W., 1988. Characteristics, dynamics and significance of marine snow, Prog. Oceanogr. 20, 41-82.

Aller, J. Y, \& Aller, R. C., 1986. Evidence for localized enhancement of biological activity associated with tube and burrow structures in deep-sea sediments at the HEBBLE site, western North Atlantic. - Deep Sea Res. 33, 755-790.

Aller, R. C. \& Yingst, J, Y., 1978. Biogeochemistry of tube dwellings: a study of the sedentary polychaete Amphitrite ornata (Leidy). - J. mar. Res. 36, 201-354.

Barnett, P. R. O., Watson, J. \& Conelly, D., 1984. A multiple corer for taking virtually undisturbed samples from shelf, bathyal and abyssal sediments. - Oceanologica Acta 7, 399-408.

Berner, R. A., 1980. Early diagenesis - a theoretical approach. Princeton Univ. Press, Princeton, $421 \mathrm{pp}$.

Billen, G., 1982. Modelling the process of organic matter degradation and nutrient recycling in sedimentary systems. In: Sediment microbiology. Ed. by D. B. Nedwell \& C. M. Brown. Açad. Press, London, 15-52.

Boetius, A., 1992. Extrazelluläre hydrolytische Enzymaktivitäten als Parameter für mikrobielle Prozesse in Tiefseesedimenten. Dipl.Arb., Univ. Hamburg, 85 pp.

Chrost, R. J., 1991. Environmental control of the synthesis and activity of aquatic microbial 
ectoenzymes. In: Microbial enzymes in the aquatic environment. Ed. by R. J. Chrost. Springer, New York, 29-59.

Deming, J. W. \& Yager, P. L., 1992. Natural bacterial assemblages in deep-sea sediments: towards a global view. In: Deep-sea food chains and the global carbon cycle. Ed. by G. T. Rowe \& V. Pariente. Kluwer, Dordrecht, 11-28.

Emerson, S., Fischer, K., Reimers, C. E. \& Heggie, D., 1985. Organic carbon dynamics and preservation in deep-sea sediments. - Deep Sea Res. 32, 1-21.

Gaillard, J. F. \& Rabouille, C., 1992. Using Monod kinetics in geochemical models of organic carbon mineralization in deep-sea surficial sediments. In: Deep-sea food chains and the global carbon cycle. Ed. by G. T. Rowe \& V. Pariente. Kluwer, Dordrecht, 309-323.

Hoppe, H.-G., 1983. Significance of exoenzymatic activities in the ecology of brackish water: measurements by means of methylumbelliferyl-substrates. - Mar. Ecol. Prog. Ser. 11, 299-308.

IUB/IUPAC, 1973. Enzyme nomenclature. Elsevier, Amsterdam, 443 pp.

Karl, D. M., Knauer, G. A. \& Martin, J. H., 1988. Downward flux of particulate organic matter in the ocean: a particle decomposition paradox. - Nature, Lond. 332, 428-440.

King, G. M., 1986. Characterization of $\beta$-glucosidase activity in intertidal marine sediments. - Appl. environ. Microbiol. 51, 373-380.

Köster, M. \& Meyer-Reil, L. A., 1991. Hydrolytic activities of organisms and biogenic structures in deep-sea sediments. In: Microbial enzymes in aquatic environments. Ed. by R. J. Chrost. Springer, New York, 298-310.

Lochte, K., 1992. Bacterial standing stock and consumption of organic carbon in the benthic boundary layer of the abyssal North Atlantic. In: Deep-sea food chains and the global carbon cycle. Ed. by G. T. Rowe \& V. Pariente. Kluwer, Dordrecht, 1-10.

Lochte, K. \& Rheinheimer, G., 1990. Bakterien im Sediment und bodennahem Wasser. - Ber. Zent. Meeres-Klimaforsch. 10,55-77.

Meyer-Reil, L. A., 1986. Measurement of hydrolytic activity and incorporation of dissolved organic substrates by microorganisms in marine sediments. - Mar. Ecol. Prog. Ser. 31, 143-149.

Meyer-Reil, I. A., 1987. Seasonal and spatial distribution of extracellular enzymatic activities and microbial incorporation of dissolved organic substrates in marine sediments. - Appl. environ. Microbiol. 53, 1748-1755

Meyer-Reil, L. A., 1991. Ecological aspects of enzymatic activities in marine sediments. In: Microbial enzymes in aquatic environments. Ed. by R. J. Chrost. Springer, New York, 84-95.

Pfannkuche, O., 1992. Organic carbon flux through the benthic community in the temperate abyssal northeast Atlantic. In: Deep-sea food chains and the global carbon cycle. Ed. by G. T. Rowe \& V. Pariente. Kluwer, Dordrecht, 183-197.

Pfannkuche, O., Beckmann, W., Christiansen, B., Lochte, K., Rheinheimer, K., Thiel, H. \& Weikert, H., 1990. Biologischer Vertikaltransport und Energiehaushalt in der bodennahen Wasserschicht der Tiefsee. - Ber. Zent. Meeres-Klimaforsch. 10, 1-159.

Priest, F. G., 1984. Extracellular enzymes. - Aspects Microbiol. 9, 1-79.

Rice, D. L., 1982. The detritus nitrogen problem: new observations and perspectives from organic geochemistry. - Mar. Ecol. Prog. Ser. 9, 153-162.

Rowe, G. T., Sibuet, M., Deming, J., Khripounoff, A., Tietjen, J., Macko, S. \& Theroux, R., 1991. "Total" sediment biomass and preliminary estimates of organic residence time in deep-sea benthos. - Mar. Ecol. Prog. Ser. 79, 99-114.

Smucker, R. A. \& Kim, C. K., 1991. Chitinase activity in estuarine waters. In: Microbial enzymes in aquatic environments. Ed. by R. J. Chrost. Springer, New York, 249-269.

Tietjen, J. H., 1992. Abundance and biomass of metazoan meiobenthos in the deep-sea. In: Deepsea food chains and the global carbon cycle. Ed. by G. T. Rowe \& V. Pariente. Kluwer, Dordrecht, 45-62.

Westrich, J. T. \& Berner, R. A., 1984. The role of sedimentary organic matter in bacterial sulfate reduction: the "G"-model tested. - Limnol. Oceanogr. 29, 236-249. 